\title{
NUTRITIVE VALUE AND CHEMICAL QUALITY INDICATORS OF IMPORTED CATTLE'S LIVER
}

\author{
AHMED, H.Y. ${ }^{1}$; ABD-ALLAH SH.M.S. ${ }^{2}$; MOHAMMED, D.B. ${ }^{3}$ \\ ${ }^{1,2,3}$ Meat hygiene group, Department of Food Hygiene, Faculty of Veterinary Medicine, Assiut \\ University, 71526, Assiut, Egypt.
}

Received: 24 December 2020; Accepted: 5 January 2021

\begin{abstract}
The present study was conducted to assess the quality of imported frozen liver sold in Assiut markets, Egypt. A total of 100 samples were randomly collected over a 2 months period (January to March, 2020) from poultry slaughter shops, supermarkets and frozen meat markets. The liver samples were evaluated for chemical indicators of spoilage $(\mathrm{pH}, \mathrm{TVBN}$ "Total Volatile base nitrogen", and TBA "Thiobarbituric acid") and some of the nutritional aspects (percentage of moisture, protein, fat, ash, and carbohydrates, as well as, gross energy (Kcal/100g) and cholesterol content $(\mathrm{mg} / 100 \mathrm{~g})$, beside levels of iron $(\mathrm{mg} / 100 \mathrm{~g})$. The obtained mean values of $\mathrm{pH}, \mathrm{TVBN}(\mathrm{mg} / 100 \mathrm{~g})$ and TBA $(\mathrm{mg} / \mathrm{kg})$ of the examined samples were 6.38 $\pm 0.01,25.76 \pm 0.44$, and $0.65 \pm 0.03$, respectively. Of the examined samples, $92 \%$ showed $\mathrm{pH}$ value exceeded the permissible limits of Egyptian standards; however, $88 \%$ showed TVBN content within the set limit. The mean values of moisture, protein, fat, ash and carbohydrates $(\%)$ were $70.54 \pm 0.11,21.64 \pm 0.08,3.58 \pm 0.12,1.50 \pm 0.018$, and $2.74 \pm 0.11$, respectively. The calculated gross energy mean value was of $133.09 \pm 1.06 \mathrm{Kcal} / 100 \mathrm{~g}$. Additionally, the cholesterol and iron content mean values were $130.85 \pm 2.17 \mathrm{mg} / 100 \mathrm{~g}$ and $16.07 \pm 0.24 \mathrm{mg} / 100 \mathrm{~g}$, respectively in the examined imported frozen liver samples. In conclusion, imported frozen liver sold in markets of Assiut city Egypt is of fair quality; it should be consumed sporadically and with care of TBARS, cholesterol and iron potential hazards.
\end{abstract}

Keywords: Imported frozen liver, Chemical quality, Nutritional aspects

\section{INTRODUCTION}

The definition of "meat" includes offal such as liver, kidney, spleen, etc. A specific feature of meat and offal is their nutritive elements, including high-quality protein, fat, mineral and vitamin content. They are

Corresponding author: AHMED, H.Y.

E-mail address: yossefh46@yahoo.com; hussien.youssif@vet.au.edu.eg

Present address: Meat hygiene group, Department of Food Hygiene, Faculty of Veterinary Medicine, Assiut University, 71526, Assiut, Egypt. protein-rich and low-carbohydrate products assumed to be beneficial with respect to obesity, diabetes development and cancer (Insulin resistance hypothesis) (Cabrera and Saadoun, 2014 and Biel et al., 2019).

Liver as an example of offal has a high nutritional value. It is a good source of amino acids and fatty acids. Protein from liver has almost all the essential and nonessential amino acids, as well as many polyunsaturated fatty acids (PUFA) which is good for health as they reduce the cholesterol. In addition, the levels of certain 
minerals, such as iron, zinc, magnesium, and calcium, are higher in beef liver than in muscular tissue (Florek et al., 2012 and Taniguchi et al., 2017). Moderate consumption of bovine liver can prevent anemia, maintain normal visual function, reproductive function, maintain the integrity of epithelial cell structure, promote children's growth and development, improve exercise capacity, anti-aging, anti-oxidation, and prevent the occurrence of cancer (Katan et al., 1994 and Guo et al., 2018).

As livers contain higher enzyme activity than meat, they may have a shorter shelf life. In order to be long stored, liver must be frozen. Frozen imported liver, however encounter a lot of circumstances that differ its composition and quality, including storage temperature, humidity and bacterial load during shipping, as well as other hygienic practices and treatments of the handlers and retailers applied to the imported liver (Creed and James, 2006 and Guo et al., 2018).

The freshness of frozen liver must be determined; TVBN testing has been made mandatory by official authorities and private companies. Additionally, the current method commonly used for the assays of lipid oxidation include thiobarbituric acid (TBA) (Guo et al., 2018).

The major chemical components analysis such as proteins, fats, carbohydrates, minerals and fatty acids contents was applied as measurement of quality. The chemical composition of liver varies greatly depending on genotype, age, gender, rearing system, environment and season (Cheung and Mehta, 2015).

Cholesterol, the main sterol present in animal tissues, present at higher levels in brain, liver and kidney than in meat tissue. It has essential role in lipid metabolism and other vital processes inside the body while high amount of it leads to adverse effect on consumer health being associated with chronic heart diseases (Dessi and Batetta, 2003 and Ockerman and Basu, 2014).

Imported liver is considered as an important protein source used to solve shortage in protein of animal origin in Egypt. Frozen liver are imported to Egypt from various countries around the world, with increasing imports year after year to cover the shortfall in domestic production. It is preferable by Egyptian consumers because it is considered cheap compared with meat. The major suppliers of frozen beef liver to Egypt are United States, Brazil, Australia, New Zealand and India (USDA/ FAS, 2018).

Not so much information is available regarding the quality of freeze stored bovine liver in Egypt. Studies on frozen imported liver concerning its nutritional value and quality are limited particularly in Upper Egypt. So, the present study was planned to fulfill the following points as to evaluate the chemical quality of frozen imported liver sold in Assuit city, Egypt; determine chemical indicators of spoilage ( $\mathrm{pH}, \mathrm{TVBN}$, and TBA values), the proximate composition (moisture, protein, fat, ash, and carbohydrates percentages), the cholesterol, as well as the iron contents.

\section{MATERIALS AND METHODS}

\section{Collection of samples}

A total number of 100 imported frozen liver samples (each about $250 \mathrm{~g}$ weight) with no restrictions considering age or production date were randomly collected over 2 months period (January to March, 2020) from poultry slaughter shops, supermarkets and frozen meat markets in Assiut city. Of the samples 76 were originated from America, 8 from Brazil, 8 from Australia, 5 from Denmark, 1 from New Zealand, and 2 were unknown origin. The collected samples were separately placed in polyethylene bags and transferred directly to the laboratory of Meat Hygiene Section, Department of Food Hygiene, Faculty of Veterinary Medicine, Assiut University, in an ice box with a 
minimum of delay where they were sensory evaluated and prepared for the prescribed analysis.

\section{Sensory evaluation of the samples:}

The organoleptic evaluation was focused on detection of objectionable appearance, odor or texture. If any faults were found, then they would be reported.

\section{Preparation of samples (Pierson, 1982):}

At the laboratory, firstly frozen liver were thawed at refrigerator at $4{ }^{\circ} \mathrm{C}$. Subsamples were taken from an internal, unexposed surface with care to exclude any connective tissue or large bile ducts. The subsamples were cut separately into small size pieces and then thoroughly mixed into mortar to obtain a uniform mass.

\section{Determination of $\mathrm{pH}(\mathrm{AOAC}, 1990)$ :}

Five grams of prepared samples was stomached with $45 \mathrm{ml}$ of distilled water at $25^{\circ} \mathrm{C}$ in stomacher bag for $2 \mathrm{~min}$, then left for $10 \mathrm{~min}$. Buffers calibrated $\mathrm{pH}$ meter (SD $50 \mathrm{pH}$ meter, Germany) was used to determine $\mathrm{pH}$ of the sample.

\subsection{Determination of Total volatile base} nitrogen (TVBN) according to Pearson (1976):

Homogenized diluted sample was transferred to 1-liter distillation flask. Two $g$ of magnesium oxide and antifoaming agent were added to the mixture in the flask to avoid excessive foaming.

In receiving flask, $25 \mathrm{ml}$ of $2 \%$ boric acid solution and a few drops of screened methyl red indicator were added. The distilling flask was heated then the obtained distillate was titrated against $0.05 \mathrm{M}(0.1 \mathrm{~N})$ sulphuric acid till end point (faint yellow color). Blank sample was done with the same procedures excluding the sample.

The amount of $0.1 \mathrm{~N}$ sulphuric acid exhausted in titration was recorded then TVBN was calculated according to the following formula:

TVBN $=($ Titration - blank $) \times 14$

\subsection{Determination of Thiobarbituric acid- Reactive Substances measurement (TBARS):}

Of the wet sample, 3 grams were used for determination according to Ahn et al. (2008). The sample absorbance was read against the blank at $531 \mathrm{~nm}$ on the spectrophotometer (Unico, 2100 UV, USA); and the value of TBARS in the sample was calculated from the standard curve, and was expressed as mg of malondialdehyde (MDA) per $\mathrm{kg}$ of liver tissue, taking into consideration the sample dilution factor " $=6$ " as following:

Sample TBARS content (mg MDA/kg tissue) $=\frac{(\text { Sample absorbance }-0.045)}{0.9615} \times 6$

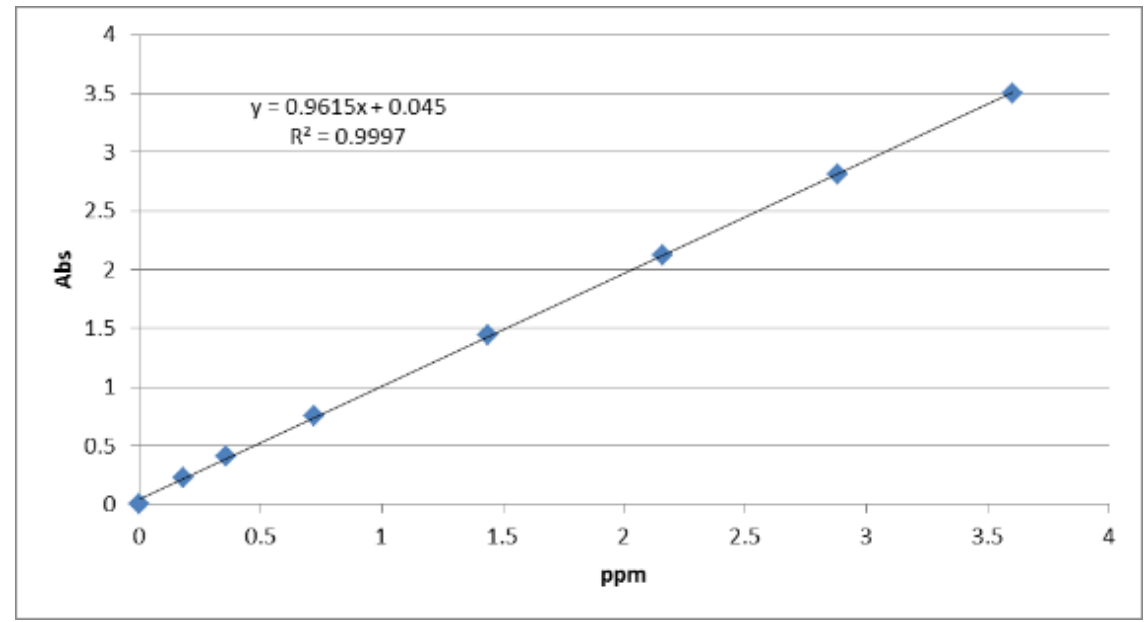




\section{Proximate composition analysis}

The samples were analyzed in duplicates

\subsection{Determination of moisture percentage} (AOAC, 2012):

\subsection{Determination of crude protein percentage "Biuret method" (Reichardt and Eckert, 1991):}

Of the wet sample 0.5 gram was used. The sample absorbance was read against the blank at $540 \mathrm{~nm}$ on the spectrophotometer (Unico, $2100 \mathrm{UV}, \mathrm{USA}$ ); and the sample protein concentration was determined from the prepared standard curve as following:

Sample protein concentration $=$ $\underline{\text { (Sample absorbance-0.002) }}$

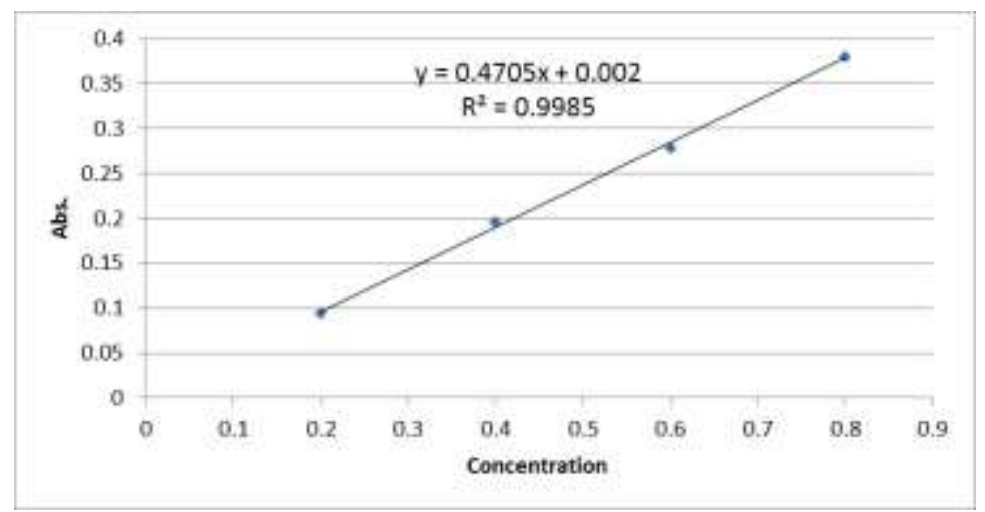

The protein percentage of the sample was calculated according the following equation: Protein $\%=$

$\frac{\text { Sample protein concentration } \times \text { dilution volume }(50 \mathrm{ml}) \times 10}{\text { Sample weight }(500 \mathrm{mg})} \times 100$

\subsection{Determination of fat percentage "ether extract method" (AOAC, 2012):}

Soxhlet method was used with slight modification: one gram of the dried sample was weighed onto dry filter paper of known weight then wrapped. The samples were then extracted with petroleum ether $(60 / 80)$ for about $16 \mathrm{hrs}$ at heating rate of $150 \mathrm{drop} /$ min. The wrapped samples were then taken out of the extraction thimble, allowed to dry for one hour at room temperature then for another 1 hour at $80-90^{\circ} \mathrm{C}$, then allowed to cool in the desiccator.

Fat $\%=\frac{W 1-W 2}{w} \times 100$

$\mathrm{W} 1=$ weight of the filter paper with the sample before extraction.

$\mathrm{W} 2$ = weight of the filter paper with the sample after extraction.

$\mathrm{W}=$ weight of the sample.
6.4. Determination of ash content (AOAC, 2012):

One gram of the dried liver sample was ignited in porcelain crucible using the muffle furnace (Thermo Scientific, Thermolyne 6000 Furnace, USA) at $550-600^{\circ} \mathrm{C}$ for 6 hours.

$$
\text { Ash } \%=\frac{\text { Weight of ash }}{\text { Weight of sample }} \times 100
$$

The obtained results on dry weight basis were converted to wet weight basis using equation of Jurgens and Bregendahl (2007)

\subsection{Calculation of the total carbohydrates (AOAC, 2012):}

The total carbohydrate was obtained using the following equation:

Total carbohydrate $\%=$ 100 - (Moisture $\%+$ protein $\%$ (wet basis) + fat $\%$ (wet basis) + ash $\%$ (wet basis)

\subsection{Calculation of gross energy value:}

The gross energy value was calculated according to the equation of Merrill and Watt (1973) as the following:

Gross energy value $(\mathrm{kcal} / 100 \mathrm{~g})=$ $($ Protein\% x 4) $+($ Fat\% x 9) $+($ Carbohydrate\% x 4) 


\section{Determination of cholesterol:}

7.1. Extraction of fat from liver tissue According to the procedures of Bligh and Dyer (1959), followed by preparation of the lipid extract for cholesterol determination according to Naeemi et al. (1995).

\subsection{Determination of cholesterol:}

According to Pasin et al. (1998), enzymatic determination of cholesterol using procedures of diagnostic kits (CHOD-PAP, Ref: 230001, Spectrum, S.A.E.) was applied. The absorbance of specimens and standard were measured against reagent blank within 30 minutes using the spectrophotometer (Unico 2100UV, USA) at wave length 546 nm.

Cholesterol content "mg/100 g" $=\frac{\text { A sample }}{A \text { standard }} \times 200$

A sample $=$ absorbance of sample.

A standard $=$ absorbance of standard.

\section{Estimation of Iron (ISO, 1996 and 1998):}

One gram of dry sample was accurately weighted and used for the estimation. The iron content was determined by using enzymatic diagnostic iron kits (Chromazurol B, Ref: 269001, spectrum, S.A.E.), where the absorbance of specimens and standard were measured against reagent blank using the spectrophotometer (Unico, $2100 \mathrm{UV}$, USA) at wave length $623 \mathrm{~nm}$.

$\operatorname{Iron}(\mu \mathrm{l} / 100 \mathrm{~g})=\frac{\text { A sample }}{\text { A standard }} \times 200($ dry basis $)$

A sample $=$ Absorbance of the sample.

A standard $=$ Absorbance of the standard.

Iron "wet basis" $(\mathrm{mg} / 100 \mathrm{~g})=$

$\frac{\text { Iron dry basis } \times \text { dry matter }}{100} \times$ dilution $(100 \mathrm{ml}) \times 1000$

\section{Statistical analysis:}

Statistical analysis of the data was performed using Excel Microsoft software Inc. 2010. Data were presented as minimum, maximum, and mean $\pm \mathrm{SE}$.

\section{RESULTS}

The obtained results were recorded in Tables $1,2,3,4,5$ and 6.

Table 1: Results of sensory evaluation of the examined liver samples $(n=100)$

\begin{tabular}{ccccccc}
\hline \multirow{2}{*}{ Number } & \multicolumn{2}{c}{ Odor } & \multicolumn{2}{c}{ Appearance } & \multicolumn{2}{c}{ Texture } \\
\cline { 2 - 7 } & $\mathrm{N}$ & $\%$ & $\mathrm{~N}$ & $\%$ & $\mathrm{~N}$ & $\%$ \\
\hline Normal samples & 69 & 69 & 72 & 72 & 90 & 90 \\
\hline $\begin{array}{c}\text { Unordinary } \\
\text { samples }\end{array}$ & 31 & 31 & 28 & 28 & 10 & 10 \\
\hline
\end{tabular}

Table 2: Statistical analytical results of $\mathrm{pH}, \mathrm{TVBN}(\mathrm{mg} / 100 \mathrm{gm})$ and TBA (mg malonaldehyde/kg) values of the examined imported frozen liver samples $(n=100)$

\begin{tabular}{ccccc}
\hline Item & Min & Max & Mean & SE \\
\hline pH & 6.13 & 6.60 & 6.38 & 0.01 \\
\hline TVBN & 16.8 & 42 & 25.76 & 0.44 \\
\hline TBA & 0.07 & 1.93 & 0.65 & 0.033 \\
\hline
\end{tabular}


Table 3: Imported liver samples acceptability according to $\mathrm{pH}$, TVBN and TBARS contents $(\mathrm{n}=100)$

\begin{tabular}{|c|c|c|c|c|c|c|c|c|}
\hline \multirow{3}{*}{ Item } & \multicolumn{4}{|c|}{ pH } & \multicolumn{2}{|c|}{$\mathbf{T V B N}^{3}$} & \multicolumn{2}{|c|}{ TBARS $^{4}$} \\
\hline & \multicolumn{2}{|c|}{ ES $(2007)^{1}$} & \multicolumn{2}{|c|}{$\operatorname{ES}(2005 b)^{2}$} & \multirow{2}{*}{ No. } & \multirow{2}{*}{$\%$} & \multirow{2}{*}{ No. } & \multirow{2}{*}{$\%$} \\
\hline & No. & $\%$ & No & $\%$ & & & & \\
\hline $\begin{array}{l}\text { Within } \\
\text { permissible } \\
\text { limits } \\
\end{array}$ & 8 & 8 & 100 & 100 & 88 & 88 & 77 & 77 \\
\hline $\begin{array}{l}\text { Exceed } \\
\text { permissible } \\
\text { limit }\end{array}$ & 92 & 92 & 0 & 0 & 12 & 12 & 23 & 23 \\
\hline \multicolumn{9}{|c|}{$\begin{array}{l}{ }^{1} \mathrm{pH} \text { limits stated in ES }(2007) \text { were } 5.5-6.2 \text {. } \\
{ }^{2} \mathrm{pH} \text { limits stated in ES }(2005 \mathrm{~b}) \text { were } 6-6.8 . \\
{ }^{3} \text { TVBN limit stated in ES }(2007) \text { was } \leq 30 \mathrm{mg} \mathrm{N} / 100 \mathrm{~g} . \\
{ }^{4} \text { TBARS limit stated in ES (2005a) was } \leq 0.9 \text { Malondialdehyde / Kg. }\end{array}$} \\
\hline \multicolumn{9}{|c|}{$\begin{array}{l}\text { Table 4: Statistical analytical results of moisture, protein, fat, ash and carbohydrate content }(\%) \\
\text { the examined imported frozen liver samples }(\mathrm{n}=100)\end{array}$} \\
\hline Item & & Min & & & & & & \\
\hline Moisture & & 65.53 & & & & & & \\
\hline Protein & & 18.49 & & & & & & \\
\hline Fat & & 1.95 & & & & & & \\
\hline Ash & & 0.95 & & & & & & \\
\hline Carbohydrat & & 0.37 & & & & & & \\
\hline
\end{tabular}

Table 5: Statistical analytical results of gross energy content (Kcal/100 g); percentage of energy from protein, fat or carbohydrate of the examined imported frozen liver samples $(n=100)$.

\begin{tabular}{lcccc}
\hline \multicolumn{1}{c}{ Item } & Min & Max & Mean & SE \\
\hline Gross energy & 114.59 & 199.30 & 133.09 & 1.06 \\
\hline Protein energy (\%) & 48.62 & 75.10 & 67.76 & 0.47 \\
\hline Fat energy (\%) & 14.21 & 50.11 & 23.92 & 0.59 \\
\hline Carbohydrate energy (\%) & 0.88 & 17.90 & 8.30 & 0.34 \\
\hline
\end{tabular}

Table 6: Statistical analytical results of Cholesterol and Iron content $(\mathrm{mg} / 100 \mathrm{~g})$ of the examined imported frozen liver samples ( $\mathrm{n}=100)$.

\begin{tabular}{ccccc}
\hline Item & Min & Max & Mean & SE \\
\hline Cholesterol & 97.36 & 195.48 & 130.85 & 2.17 \\
\hline Iron & 10.69 & 24.15 & 16.07 & 0.24 \\
\hline
\end{tabular}

\section{DISCUSSION}

Liver perhaps, is the most consumed byproduct worldwide. Imported frozen liver is considered a nutrition dense food being cheap compared with red meat. It however, encounters a lot of circumstances that affect its composition and quality (Marti et al., 2011 and Lawrie, 2017).
Deterioration of quality in food manifests itself most conspicuously through changes in appearance, odor, flavor, color and/or texture. For this reason, sensory methods for evaluation of such products are effective and are frequently applied (Hernandez-Herrero et al., 1999). 


\section{SENSORY EVALUATION}

Sensory examination of imported frozen liver samples reveals that $31 \%$ showed unordinary odor. Odors recognized in samples were very intense metallic odor, slight decomposition, fecal odor or incense odor from the market. $28 \%$ of the examined samples showed unusual appearance. Black color was the most common unordinary appearance seen. However, greenish, yellowish, paleness or uneven color was also noticed. The percentage of liver sample recorded abnormal texture was $10 \%$. The main textural changes observed were softness, very greasy, friable, and firmness "due to high connective tissue content". In addition, visual examination revealed that livers are packaged and shipped to the retail markets without removing capsula fibrosa, large blood vessels and ducts along the external surface of the livers (Table 1).

\section{CHEMICAL QUALITY INDICATORS:}

\section{The pH:}

The $\mathrm{pH}$ is considered one of the most critical parameters in meat and meat product quality as it determines their shelf life and functional properties. The determination of $\mathrm{pH}$ was considered as a valuable indicator to judge the freshness of beef livers (Hanna et al., 1982 and Florek et al., 2012).

The data of $\mathrm{pH}$ in Table (2) declared that the values were ranged from 6.13 to 6.6 with mean value of $6.38 \pm 0.01$, nearly similar findings were reported by many researchers (El-Tokhey, 1989; Moustafa, 1999; Mohie El-din, 2000; Selim et al., 2015; Salem et al., 2017; Meghawry, 2020 and Hassan et al., 2020).

Regarding ES (2007), $92 \%$ of the samples showed $\mathrm{pH}$ values higher than the permissible limit "value of $\geq 5.5-\leq 6.2$ " (Table 3). However, according to ES (2005b) all samples (100\%) were within the acceptable limit.
Selim et al. (2015) recorded that 92 and 91.7 $\%$ of the imported frozen liver samples from port and markets, respectively, were within the acceptable limits stipulated by the Egyptian standards "2007" which disagree with the current findings. Meghawry (2020) recorded that 70 and $76.7 \%$ of imported liver samples collected from slaughter shops and supermarkets, respectively were within the acceptable limits stipulated by the Egyptian standards "2005".

It is worth to declare that $\mathrm{pH}$ values mentioned in ES (2007) is not compatible with values recorded by Pierson (1982) and Moustafa (1999) who stored liver for 4 and 7 months, respectively in an attempt to detect the onset of deterioration occurred in frozen stored liver, and found $\mathrm{pH}$ values of frozen liver in the range of $6.44-6.54$ and 5.77 6.44 , respectively.

Changes in the $\mathrm{pH}$ of muscle after slaughter are due to the accumulation of lactic acid from anaerobic glycolysis (Hunt, 2011). Liver metabolism, however is more complex than skeletal muscle. Liver is the site of the urea cycle where ammonia from deamination reaction is converted to urea for excretion. As well, bile secretion is an exocrine function of liver; the $\mathrm{pH}$ of bile is 7.5. On the other hand, it contains lysosomes with lytic enzymes that are generally acidic; release of these or other organelle contents would affect liver $\mathrm{pH}$ (Harper, 1975). A drop in liver $\mathrm{pH}$ could be expected in this postmortem anaerobic environment due to the accumulation of lactic acid. However, under vacuum packaging, the beef liver $\mathrm{pH}$ increases (Pierson, 1982). One possible explanation for this effect of packaging could be; greater build-up of ammonia and other nitrogenous compounds under vacuum packaging as the necessary enzyme systems for their production would be available (Harper, 1975). Meanwhile, under atmospheric packaging the greater gas headspace would allow for greater dilution of any ammonia gas present. 


\section{Total Volatile Base Nitrogen (TVBN):}

Liver tissue spoils faster than meat which causes practical problems when trading. This occurs as a result of liver tissue exposure to many critical points including chemical and microbial pollutants; leading to deterioration of their quality and spoilage (Selim et al., 2015). In this context, TVBN estimation was used to measure degree of freshness of liver tissue.

The results of TVBN values declared in Table (2) were in harmony with Selim et al. (2015), who found that TVBN values in imported frozen liver samples from port and market were in the range of $23.8-29.4$ and 26.6 - $30.8 \mathrm{mg} / 100 \mathrm{~g}$ with mean value of 23.25 and $28.48 \mathrm{mg} / 100 \mathrm{~g}$, respectively.

However, it was higher than the findings of Meghawry (2020) who found TVBN values were in the range of $15.08-31.79$ and 9.91 22.16 with mean value of $19.33 \pm 0.95$ and $13.82 \pm 0.78 \mathrm{mg} / 100 \mathrm{~g}$ in imported liver samples taken from shops and supermarkets, respectively. Also, Salem et al. (2017) recorded that TVBN in samples of frozen liver and values were ranged from 2.97 to 11.86 with mean of $6.99 \pm 0.28 \mathrm{mg} / 100 \mathrm{~g}$. However, Moustafa (1999) reported that TVBN values were ranged from 6.12 to $46.35 \mathrm{mg} / 100 \mathrm{~g}$, in local liver samples kept frozen up to 7 months, which partially coincide with the current findings.

Of the 100 tested samples, $88 \%$ had TVBN values agreed to the Egyptian standards (2007), while $12 \%$ exceed the allowed limit (Table 3).

This result differs than the findings reported by Selim et al. (2015) who found that 100 and $96 \%$ of the imported frozen liver samples from port and markets were within the acceptable limit; and also Meghawry (2020) who recorded that $93.3 \%$ and $100 \%$ of imported liver samples collected from slaughter shops and supermarkets, respectively were within the limits stipulated by the Egyptian standards.

\section{Thiobarbituric acid reactive substance (TBARS):}

One of the most important causes of meat food deterioration is lipid oxidation, which affects fatty acids, particularly polyunsaturated fatty acids (Fennema, 1993). Oxidative rancidity development is a time related chain reaction being catalyzed by heme-pigment. TBA test measures malondialdehyde, an intermediate of lipid oxidation. The test is not considered a reliable measurement for highly oxidized products; as malonaldehyde may react with amines resulting in lower than expected TBA values (Pierson, 1982).

Values of TBARS in Table (2) were lower than the results reported by Meghawry (2020) who found that TBA values in imported liver obtained from shops and supermarkets were ranged from 0.44 to 0.71 and 0.3 to 0.52 with mean values of $0.58 \pm$ 0.05 and $0.39 \pm 0.03$, respectively.

Pierson (1982) found average TBA value of liver kept frozen up to 16 weeks at $-23^{\circ} \mathrm{C}$ was $0.701 \mathrm{mg} / \mathrm{kg}$, while Moustafa (1999) determined TBA values ranged from 0.04 to $0.48 \mathrm{mg} / 100 \mathrm{~g}$ in liver samples kept frozen up to 7 months at $-18^{\circ} \mathrm{C}$.

This lipid autoxidative degradation resulted in some products that change the food quality including the color, aroma, flavor, texture and even the nutritive value (Fennema, 1993). The rancid flavor is initially detected in meat when TBA values lies between 0.5 and $2.0 \mathrm{mg} / \mathrm{Kg}$, (Habbal, 2000).

Malondialdehyde is an intermediate peroxidation product of polyunsaturated fatty acids. Beside its effect on sensory properties of meat and meat products it is hazardous to human health as its consumption may predispose for various illnesses like cancer, CVD, etc., leading to high morbidity and mortality (Laaksonen et al., 2005). 
Considering Malondialdehyde in liver, established permissible limit was not found. However, $0.9 \mathrm{mg} / \mathrm{kg}$ were considered as the permissible limit for rancidity in frozen meat. Concerning this and according to ES (2005a), 23\% of the examined liver samples may consider unfit (exceed the permissible limit of $0.9 \mathrm{mg} / \mathrm{kg}$ ).

\section{PROXIMATE CHEMICAL COMPOSITION OF LIVER TISSUE SAMPLES}

\section{Moisture content:}

It was reported that the moisture content of meat decreased with an increase of the freeze storage period (Hammad et al., 2019).

The moisture content (\%) of examined imported frozen liver samples illustrated in Table (4) showed values ranged from 65.53 to 74.09 with a mean of $70.54 \pm 0.11$.

Matportalen (2006); Taniguchi et al. (2017); Kakimov et al. (2018) and Biel et al. (2019) detected values of moisture in fresh liver samples were $72,76.6 \pm 0.2,74.90 \pm 1.68$, and $70.00 \pm 0.53 \%$, respectively. As well, Sandulachi and Gornet (2012), in a bibliographic study reported that moisture content of cattle liver was $71.7 \%$.

\section{Protein content:}

Liver is a valiable source of high-quality protein, contains all essential amino acids (Bayomy and Rozan, 2017).

Data in Table (4) showed the protein content of examined imported frozen liver samples, which was lower than the findings reported by Selim et al. (2015) who found that protein content of 18.6 to 35.4 , and 17.8 to 30 with mean value of 24.4 and $23.8 \%$, respectively in imported frozen liver samples from port and market, in Port Said, Egypt.

Many researchers such as Matportalen (2006); Ockerman and Basu (2014); Biel et al. (2019) and Kakimov et al. (2018) determined the protein contents of fresh liver were $20.3,19.0-22.9,20.30 \pm 0.28$, and $18.9 \pm 0.53 \%$, respectively. Sandulachi and
Gornet (2012) in a bibliographic study reported that liver contain $17.9 \%$ of protein.

\section{Fat content:}

The values in Table (4) showed that the fat content of the examined imported liver samples varied from 1.95 to $11.1 \%$ with a mean value of $3.58 \pm 0.12 \%$.

Matportalen (2006); EL-Shamy (2011); Kakimov et al. (2018) and Biel et al. (2019) showed that fat content of raw fresh liver tissue was $3.2,3.50 \pm 0.53,3.80 \pm 0.11$, and $3.60 \pm 0.92 \%$, respectively. Sandulachi and Gornet (2012) in a bibliographic study reported that fat content represent $3.7 \%$ of liver tissue, while Ockerman (2014) pointed out that fat content could vary from 3.8 to $7.8 \%$.

\section{Ash content:}

Ash is a measure of the mineral content of food. It is the inorganic residue that remains after the organic matter has been burnt off (Nielsen, 2017).

Data in Table (4) showed that the ash content of the examined imported liver samples were ranged from 0.95 to 2.39 with a mean value of $1.50 \pm 0.018 \%$. Bayomy and Rozan (2017); Kakimov et al. (2018) and Biel et al. (2019) mentioned that averages ash content in fresh liver samples were $4.22 \pm 0.08,1.80 \pm 0.05$ and $1.30 \pm$ $0.19 \%$, respectively. Sandulachi and Gornet (2012) in a bibliographic study reported that ash content in liver was $1.4 \%$.

\section{Carbohydrates}

It has been known for a long time that liver act as a reserve for glycogen. The result in Table (4) showed that the carbohydrate content of the examined frozen imported liver samples varied from 0.37 to 5.68 with a mean value of $2.74 \pm 0.11 \%$.

Matportalen (2006) found that carbohydrate content in fresh liver was $3.5 \%$, and Sandulachi and Gornet (2012), in a bibliographic study mentioned that 
carbohydrates were representing $5.3 \%$ of liver tissue.

\section{Gross energy (caloric value)}

Accurate evaluation of the energy value is essential for dealing with problems of nutrition as under-nutrition, or obesity (Merrill and Watt, 1973).

Table (5) showed the caloric value of the examined imported frozen liver samples varied from 114.59 to 199.30 with a mean value of $133.09 \pm 1.06 \mathrm{Kcal} / 100 \mathrm{~g}$.

Matportalen (2006); Kakimov et al. (2018) and Biel et al. (2019) recorded that caloric value in fresh liver was 124, 109.8 and $136 \pm$ $2.67 \mathrm{Kcal} / 100 \mathrm{~g}$, respectively. Sandulachi and Gornet (2012) in a bibliographic study mentioned that energy value of liver was $328.91 \mathrm{Kcal} / 100 \mathrm{~g}$.

Of the caloric value, $67.76 \%$ was derived from protein, $23.92 \%$ from fat and only $8.3 \%$ from carbohydrates (Table 5).

\section{IRON CONTENT}

Heme iron is ferrous iron found primarily in animal products including liver, it bounds to a porphyrin ring, as in the prosthetic groups of hemoglobin and myoglobin (Taniguchi et al., 2017). The relative importance of dietary heme is attributable to its high bioavailability compared with non-heme iron in the predominantly alkaline conditions found in the lumen of the small intestine (West and Oates, 2008).

The obtained results in Table (6) revealed that iron content of the examined imported liver samples were higher than that recorded by Taniguchi et al. (2017) who found that iron content in examined frozen liver was $5.81 \pm 0.06 \mathrm{mg} / 100 \mathrm{~g}$.

Moreover, Sandulachi and Gornet (2012) in a bibliographic study reported that iron content in liver tissue represent $6.9 \mathrm{mg} / 100$ g, while Ockerman (2014) reported that iron content could vary from 6.5 to $7.0 \mathrm{mg} / 100 \mathrm{~g}$.
The high content of iron in imported frozen liver could be due to the amount of blood retained (residual blood) in liver which varied with many factors including the slaughter method, age, sex and body weight... etc. Blood contains a high amount of hemoglobin which consists of a protein component and the iron complex of a porphyrin derivative. "Hemoglobin $=$ globin (protein) + haemochromogen (Fe II complex)" (Püntener and Schilesinger, 2000).

Regarding iron, it is both necessary to the body and potentially toxic. A study from the Indiana University School found that heme iron consumption increased the risk for coronary heart disease by $57 \%$, while no association was found between non-heme iron, which is in plant and other non-meat sources, and coronary heart disease (Hunnicutt et al., 2014).

\section{CHOLESTEROL CONTENT}

Cholesterol is an indispensable constituent of the cell membranes and brain tissue. However, the relationships of dietary cholesterol intake and the process of atherosclerosis are ambiguous. Additionally, a correlation between serum cholesterol level and mortality rate of the cardiovascular diseases was proved in many studies (Griffin, 1999).

The values in Table (6) declared that cholesterol content of the examined imported liver samples was ranged from 97.36 to $195.48 \mathrm{mg} / 100 \mathrm{~g}$ with mean value of $130.85 \pm 2.17 \mathrm{mg} / 100 \mathrm{~g}$.

Information concerning the cholesterol content of beef organ meats is limited in the literature except for the values of allowed daily intake "300 mg" emphasized in the dietary guidelines for Americans (USDA/HHS, 2010)

Matportalen (2006) determined average cholesterol content in raw fresh liver 
samples as $230 \mathrm{mg} / 100 \mathrm{~g}$, while Ockerman (2014) reported that fresh liver contains 275 $\mathrm{mg} / 100 \mathrm{~g}$.

Differences in cholesterol content among species are generally explained by variations in absorption and biosynthesis of cholesterol, lipoprotein metabolism, diet, genetic variation and body weight. In this context, cholesterol data are usually accompanied by fat content, fatty acid composition, and type of meats i.e. species or cuts. In addition, differences in the cholesterol content among various studies could be caused by analytical methodology (Rhee et al., 1982 and Bragagnolo, 2009).

In conclusion, most of the samples were organoleptically acceptable, and the majority were within acceptable limits regarding TVBN content, however their $\mathrm{pH}$ values were in accordance with the permissible limits obtained by ES (2005b) and exceeded the stipulated limits by ES (2007). Considerable percentage of the samples showed elevated TBA value. The samples were good source of protein. Cholesterol content was set below the limit of allowed daily intake; however, iron content was somewhat high.

The following is to be recommended: imported frozen liver should be moderately consumed to avoid health problems that could happen by high amounts of iron and cholesterol, as well as high levels of malondialdehyde. Attention should be paid to avoid bad hygienic practices and treatments of the handlers and retailers to the imported liver. $\mathrm{pH}$ should not be used alone to evaluate the acceptability of liver. TBA limit of frozen meat can be used for evaluation of liver acceptability. Finally, veterinary services authority (VSA) and health minister should plan to form joint committees mandated with inspecting the liver intended to be exported to Egypt, so as to ensure that imported liver is safe and fit for human consumption.

\section{REFERENCES}

A.O.A.C. (1990): Association of analytical chemist, 950.46., Washington, USA.

A.O.A.C. (2012): Official Methods of Analysis of AOAC International, 19th Edition. AOAC, Washington, DC.

Ahn, D.U.; Ko, K.Y.; Lee, E.J. and Ismail, H.A. (2008): Effect of aging time and natural antioxidants on the color, lipid oxidation and volatiles of irradiated ground beef. Meat Science, 80 (57): 582-591.

Bayomy, H.M. and Rozan, M.A. (2017): Comparative studies of amino acid, fatty acids and proximal chemical composition content of donkey, dog, camel, beef and goat liver. Egypt. J. Food Sci., 45: 95-102.

Biel, W.; Czerniawska-Piatkowska, E. and Kowalczyk, A. (2019): Offal chemical composition from veal, beef, and lamb maintained in organic production systems. Animals, 9 (8): 489-499.

Bligh, E.G. and Dyer, W.J. (1959): A rapid method of total lipid extraction and purification. Can. J. Biochem. Physiol., 37(58): 911-917.

Bragagnolo N. (2009): Cholesterol and Cholesterol Oxides in Meat and Meat Products. In: Nollet LML and Toldra F (Edts). Handbook of Muscle Foods Analysis. Florida, CRC Press. P. 187219.

Cabrera, M.C. and Saadoun, A. (2014): An overview of the nutritional value of beef and lamb meat from South America. Meat Science, 98 (3): 435-444.

Creed, P.G. and James, S.J. (2006): Heat transfer during the freezing of liver in a plate freezer. Journal of Food Science, 50 (2): 285-288.

Cheung, P.C.K. and Mehta, B.M (2015): Chemical Composition of Meat and Meat Products, Handbook of Food Chemistry, Springer-Verlag Berlin Heidelberg.

Dessi, S. and Batetta, B. (2003): Overview Intracellular Cholesterol Homeostasis: Old and New Players. In: Pani A., Dessi S., (Edts) Cell Growth and Cholesterol Esters. Kluwer Academic/Plenum Publishers, New York. pp 1-12. 
EL-Shamy, R.H.M. (2011): Quality Assurance of Internal Edible Offal Produced from Food Animals Abattoirs in Alexandria. $\mathrm{Ph}$. D, Thesis (Meat Hygiene), Faculty of Veterinary Medicine, Alexandria University, Egypt.

El-Tokhey, H. (1989): Studies on Spoilage of Some Meat. MSc. Thesis, Faculty of Agriculture, Moshtohor, Zagazig University, Egypt.

ES "Egyptian Standards" (2005a): Frozen meats. E.S: 1522 -2005, Egyptian Organization for Standardization and Quality, Egypt.

ES "Egyptian Standards" (2005b): Frozen liver. EOS 1473 - 2005, ICS: 67.120.20, Egyptian Organization for Standardization and Quality, Egypt.

ES "Egyptian Standards" (2007): Frozen Liver. EOS/1473-2007.The Egyptian Organization for Standardization and Quality Control, Egypt.

Fennema, O.R. (1993): Quimica de 10s alimentos. Ed. Acribia, Zaragoza, Spain. (Cited after: Fernández, et al., 1997).

Fernández, J.; Pérez-Álvarez, J.A. and Fernández-López, J.A. (1997): Thiobarbituric acid test for monitoring lipid oxidation in meat. Food Chemistry, 59 (3): 345-353.

Florek, M.; Litwińczuk, Z.; Skałecki, P.; Kędzierska-Matysek, M. and Grodzicki, T. (2012): Chemical composition and inherent properties of offal from calves maintained under two production systems. Meat Science, 90 (2): 402-409.

Griffin, B.A. (1999): Lipoprotein atherogenicity: an overview of current mechanisms. Proceedings of the Nutrition Society, 58 (01): 163-169.

Guo, Z.; Ge, X.; Yu, Q.; Han, L.; Zhao, H. and Cao, H. (2018): Quality predictive models for bovine liver during storage and changes in volatile flavors. International Journal of Food Properties, 21 (1): 2452-2468.

Habbal, E. (2000): Study on the Quality Control of Some Frozen Meat Products. MSc. Thesis. Faculty of Agriculture, Cairo University, Egypt.

Hammad, H.H.M.; Ma, M.; Hydamaka, A.W.; Elkhedir, A.E.; Jin, G.; Abdegadir, W.S. and Homaida, M.A. (2019): Effect of freeze and re-freeze on chemical composition of beef and poultry meat at storage period 4.5 Months (SP4.5). J. Food Process Technol. 10: 791-796.

Hanna, M.O.; Smith, G.C.; Savell, J.W.; McKeith, F.K. and Vanderzant, C. (1982): Effects of packaging methods on the microbial flora of livers and kidneys from beef or pork. J. Food Prot., 45 (1): 74-81.

Harper, H.A. (1975): Review of Physiological Chemistry, $15^{\text {th }}$ Edition. Lange Medical Publications, Los Altos, CA. pp. 394395.

Hassan, M.A.; Amin, R.A. and Meghawry, A.M. (2020): Assessement Of chemical quality of local frozen cattle's liver. Benha Veterinary Medical Journal, 38 (2): 97-100.

Hernandez-Herrero, M.M.; Roig-Sagues, A.X.; Lopez-Sabater, E.I.; Rodriguez-Jerez, J.J. and Mora-Ventura, M.T. (1999): Influence of storage temperature on the quality of beef liver; $\mathrm{pH}$ as a reliable indicator of beef liver spoilage. Journal of the Science of Food and Agriculture, 79 (14): 2035-2039.

Hunnicutt, J.; He, K. and Xun, P. (2014): Dietary iron intake and body iron stores are associated with risk of coronary heart disease in a meta-analysis of prospective cohort studies. The Journal of Nutrition, 144 (3): 359-366.

Hunt, M.C.; Honikel, K.; Puolanne, E.; Kapper, C.; Klont, R.; Young, Jette, F. and Algers, A. (2011): Fundamentals in water holding capacity (WHC) of Meat. Internet publication. Available from: http://qpc.adm.slu.se/6_Fundamentals_o f_WHC/

ISO "International Organisation for Standardization" (1996): ISO 13730: 1996 (E), Meat and meat products Determination of total phosphorus content - spectrophotometric method, Geneva, Switzerland.

ISO "International Organisation for Standardization" (1998): ISO 936:1998 (E), Meat and meat products Determination of total ash, Geneva, Switzerland.

Jurgens, M.H. and Bregendahl, K. (2007): Animal Feeding and Nutrition. $10^{\text {th }}$ 
Edition. Kendall/Hunt Publishing Company, Iowa, USA.

Kakimov, A.; Suychinov, A.; Tsoy, A.; Mustambayev, N.; Ibragimov, $\quad N$.; Kuderinova, N.; Mirasheva, G. and Yessimbekov, Z. (2018): Nutritive and biological value of liver and blood of various slaughtered animals. Journal of Pharmaceutical Research International, 22 (3): $1-5$.

Katan, M.; Zock, P. and Mensink, R. (1994): Effects of fats and fatty acids on blood lipids in humans: An overview. Am. J. Clin. Nutr., 60 (6): 1017-1022.

Laaksonen, D.E.; Nyyssonen, K.; Niskanen, L.; Rissanen, T.H. and Salonen, J.T. (2005): Prediction of cardiovascular mortality in middle-aged men by dietary and serum linoleic and polyunsaturated fatty acids. Archives of Internal Medicine, 165 (2), 193-199.

Lawrie, R.A. (2017): Lawrie's Meat Science, ( $8^{\text {th }}$ Edition). Elsevier Ltd.

Marti, D.L.; Johnson, R.J. and Mathews, Jr. (2011): Where's the (Not) Meat? Byproducts from Beef and Pork Production. A Report from the Economic Research Service. www.ers. usda.gov/media/147867.

Matportalen (2006): The Norwegian food composition table, The Norwegian Food Safety Authority, The Norwegian directorate of Health and the University of Oslo, Oslo. Available from: https://www.matvaretabellen.no

Meghawry, A.M. (2020): Chemical Assessment of Frozen Local and Imported Livers. M.V. Sc., Thesis (Meat Hygiene), Faculty of Veterinary Medicine, Benha University, Egypt.

Merrill, A.L. and Watt, B.K. (1973): Energy Value of Foods: Basis and Derivation. Agriculture Handbook No. 74, Agriculture Research Service, United States Department of Agriculture, Washington DC.

Mohie El-din, A.M. (2000): Studies on Quality and Public Health Hazard of Imported Liver. M.V.Sc. Thesis (Meat Hygiene), Faculty of veterinary medicine, Suez Canal University, Egypt.

Moustafa, W.M. (1999): Studies on Frozen Beef Liver. Ph. D, Thesis (Meat
Hygiene), Faculty of Veterinary Medicine, Zagazig University, Egypt.

Naeemi, E.D.; Ahmad, N.; Al-Sharrah, T.K. and Behbahani, M. (1995): Rapid and simple method for determination of cholesterol in processed food. J. of AOAC Int., 78 (6): 1522-1524.

Nielsen, S.S. (2017): Ash Content Determination, Food Analysis Laboratory Manual, Springer International Publishing.

Ockerman, H.W; and Basu, L. (2014): Encyclopedia of Meat Sciences, Volume 1 Elsevier Ltd, P. 104-105, 106, 108, 206, 241.

Pasin, G.; Smith, G.M. and Mahony, O.M. (1998): Rapid determination of total cholesterol in egg yolk using commercial diagnostic cholesterol reagent. Food Chemistry, $61(1,2)$ : 255259.

Pearson, D. (1976): The Analysis of foods. $7^{\text {th }}$ Edition. Longman Inc. USA.

Pierson, C.J. (1982): Influence of Time and Temperature of Frozen Storage and Packaging Method on Functional Properties and Quality Characteristics of Beef and Pork Livers. Ph.D. Thesis, Department of Animal Science, The Ohio State University, USA.

Püntener, A.G. and Schilesinger, U. (2000): Natural Dyes. Colorants for Non-Textile Applications, Elsevier Ltd, P. 382-455.

Reichardt, W. and Eckert, W. (1991): The determination of protein content of milk, cheese and meat with the use of the biuret reaction. Nahrung 35 (7): 731738.

Rhee, K.S.; Dutson, T.R. and Smith, G.C. (1982): Effect of changes in intermuscular and subcutaneous fat levels on cholesterol content of raw and cooked beef steaks. Journal of Food Science, 47 (5): 1638-1642.

Salem, N.I.; Ali, G.I.; Naema, N.A. and Abou Zeid, M.A. (2017): Impact of display and handling on the chemical and microbiological content of beef frozen liver. Assiut Vet. Med. J., 63 (153): 3442.

Sandulachi, E. and Gornet, V. (2012): Indicators correlation between nutritional aspects of meat and liver. 
Sibiu Alma Mater University Conference, Sibiu 1(6):29-31.

Selim, O.A.; Ahmed, A.M. and Soliman, A.S. (2015): Quality Loss during Frozen Storage Duration of the Imported Frozen Liver. $2^{\text {nd }}$ Conference of Food Safety, Suez Canal University, Faculty of Veterinary Medicine Volume I: 135141.

Taniguchi, C.N.; Dobbs, J. and Dunn, M.A. (2017): Heme iron, non-heme iron, and mineral content of blood clams (Anadara spp.) compared to Manila clams ( $V$. philippinarum), Pacific oysters (C. gigas), and beef liver (B. taurus). Journal of Food Composition and Analysis, 57: 49-55.

USDA/ FAS (United States department of agriculture, Foreign agriculture service)
(2018): Testing Policy Hinders Frozen Beef Liver Imports, Gain Report Number EG18024. United States department of agriculture, Foreign agriculture service. Available from: https://www.fas.usda.gov/data/egypttesting-policy-hinders-frozen-beef-liverimports

USDA/ HHS (United States department of agriculture/ Human health service) (2010): Department of agriculture/ health and human services, Dietary guidelines for Americans, $7^{\text {th }}$ edition.

West, A.R. and Oates, P.S. (2008): Mechanisms of heme iron absorption: Current questions and controversies. World Journal of Gastroenterology, 14 (26): $4101-4110$.

\section{القيمة الغذائية ومؤشرات الجودة الكيميائية لكبد الأبقار المستورد}

\section{حسين بيوسف أحمد ، شريف محمد سبي ، ضياء بخيث محمد}

E-mail: yossefh46@yahoo.com; hussien.youssif@ vet.au.edu.eg Assiut University web-site: www.aun.edu.eg

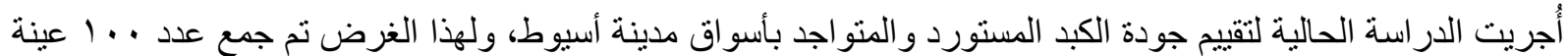

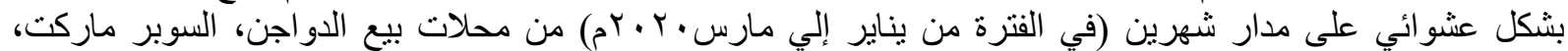

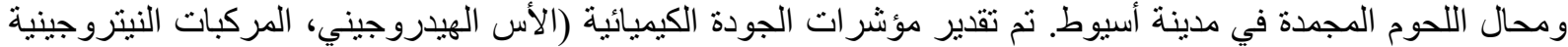

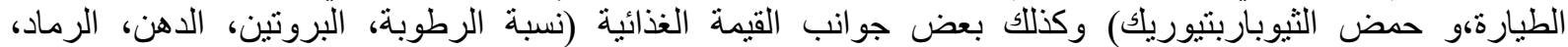

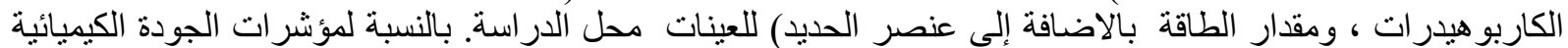

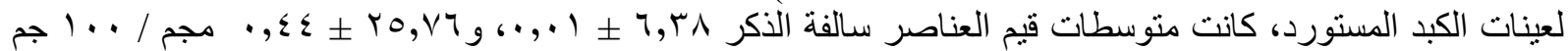

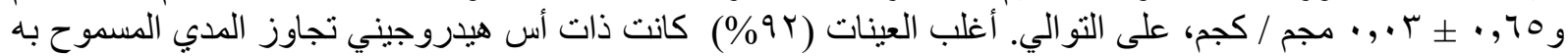

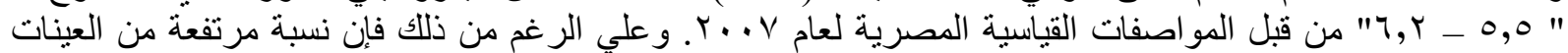

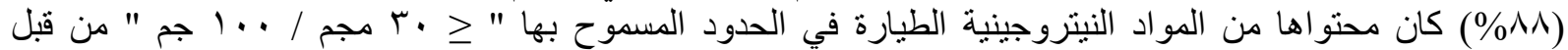

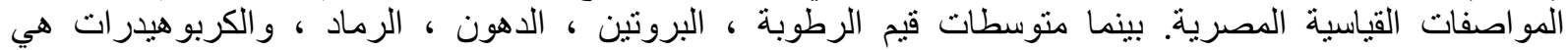
ك

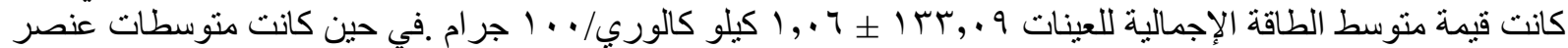

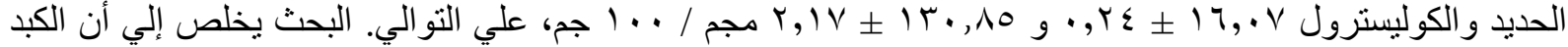

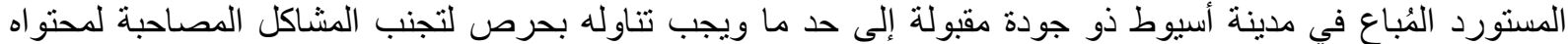
العالي من الحديد، الكولسترول ونئن اتلج الأكسدة. 